\title{
PARAPHRASE AND THE DOCTRINE OF THE TRINITY
}

\author{
Joseph Jedwab and John A. Keller
}

The Doctrine of the Trinity says that there is one God, that there are three divine Persons, and that each divine Person is God. The Logical Problem of the Trinity is that these claims seem logically inconsistent. We argue that any coherent and orthodox solution to the Logical Problem must use the technique of paraphrase: a logically or metaphysically more perspicuous reformulation. If so, discussions of paraphrase deserve more prominence in the literature on the Doctrine of the Trinity. We also show that such explicit discussion has important implications for theorizing about the Trinity.

\section{Introduction}

According to Christian orthodoxy, as stated in the Athanasian Creed,

The Father's person is one, the Son's another, the Holy Spirit's another. . . . Thus the Father is God, the Son God, the Holy Spirit God; and yet there are not three Gods, but there is one God. ${ }^{1}$

Similar claims can be found in other important creeds, Scripture, conciliar documents, and in the writings of Christian theologians from the time of Christ to the present. ${ }^{2}$ These claims constitute the core of the Doctrine of the Trinity (hereafter, "the Doctrine"). The Logical Problem of the Trinity (hereafter, "the Problem") is that the following tenets of the Doctrine seem logically inconsistent:

(1) There is exactly one God.

(2) There are exactly three divine persons.

(3) Each divine person is God.

In this paper, we argue that any solution to the Problem must involve-at least implicitly-a paraphrase of the Doctrine: a logically or metaphysically more perspicuous reformulation of (1)-(3). If this is correct, explicit thought and discussion about paraphrase deserve more prominence in the literature on the Doctrine: inattentiveness toward the

${ }^{1}$ Kelly, Athanasian Creed, 18.

${ }^{2}$ See $\$ 2.2$. 
role of paraphrase in theorizing about the Trinity leads us to underappreciate certain puzzles facing standard "solutions" to the Problem-puzzles that come to light when they are viewed, in part, as proposals for how to paraphrase (1)-(3).

We begin by explicating the notion of paraphrase and showing how standard versions of Relative-Identity, Social, and Latin Trinitarian accounts rely on this technique. Next, we argue that any solution to the Problem involves paraphrase, at least implicitly. We then explain some of the special hurdles one faces when paraphrasing carefully formulated theses like the Doctrine. Finally, we argue that explicit consideration of the nature of paraphrase provides support for Relative-Identity accounts of the Trinity - a claim that is compatible, we wish to stress, with there being conclusive reasons for preferring another account.

\section{The Method of Paraphrase}

First things first though: what is paraphrase? A paraphrase is a reformulation, a new sentence, that is intended to be more logically or metaphysically perspicuous than the original. But there are two importantly different types of reformulation, corresponding to two importantly different goals one could have in reformulating:

Revising paraphrases are intended to revise what is said: to be sentences with different and better contents than the originals. Revising paraphrases are given when some otherwise attractive sentence is false, or at least inconsistent with one's commitments. The paraphrase is then proposed as a replacement that (a) makes roughly the same claim as the original, (b) has many or all of the original's attractive features, and (c) is true, or at least consistent with one's commitments. ${ }^{3}$ Revising paraphrases are intended to be more perspicuous, then, by being more accurate - by being "strictly and literally true," as philosophers sometimes say.

Reconciling paraphrases are intended to preserve what is said: their purpose is to clarify the contents of the originals, so as to show that the originals do not need to be revised. ${ }^{4}$ Reconciling paraphrases are given when one takes some sentence to be true but misleading as to its logical or metaphysical implications. The paraphrase is intended to clarify

\footnotetext{
${ }^{3}$ Revising paraphrases are sometimes used to explain the difference between false sentences that are "good" (those that intelligent and informed people are inclined to assert) and those that are "bad" (those that intelligent and informed people are not inclined to assert). The "good" false sentences are those that are "nearly true" in virtue of the presence of a nearby truth - i.e., the revising paraphrase.

${ }^{4}$ Surprisingly, as we will see below, they don't need to do this by having the same content as the originals themselves. The terminology here is taken from Keller's, "Paraphrase, Semantics, and Ontology." Burgess and Rosen's "Nominalism," uses the labels "Revolutionary Paraphrases" and "Hermeneutic Paraphrases" for essentially the same distinction; Tuggy's "On Positive Mysterianism," similarly distinguishes between "Rational Reinterpretations" and "Revisions" of the Doctrine.
} 
those implications. Reconciling paraphrases are meant to be more perspicuous, then, in the sense of being more clear than the originals.

It is difficult to give uncontroversial examples of these two kinds of paraphrase, since whether one judges (and so could reasonably intend) a paraphrase to be reconciling or revising depends on one's overall theory. Berkeley, for example, intended to be giving (in effect) reconciling paraphrases of our talk about ordinary physical objects-paraphrases that reconcile that talk with the non-existence of matter-but most subsequent philosophers have thought that Berkeley's paraphrases were clearly revisionary. ${ }^{5}$

Applied to the Problem, revising paraphrases concede that the Doctrine, as originally formulated at least, is inconsistent and attempt to replace it with something new and improved: a consistent revision of the Doctrine. Reconciling paraphrases, on the other hand, are attempts to reconcile and so defend the logical consistency of (1)-(3): to show that the traditional Doctrine itself - the doctrine held by patristic and medieval theologiansmerely appears inconsistent and so does not need to be revised.

\subsection{The Importance of Reconciliation}

The distinction between revising and reconciling paraphrases is important, and one benefit of explicitly thinking about the role of paraphrase in theorizing about the Doctrine is that it brings this distinction to the fore. An account of the Trinity is not just an account of the properties of and relations among the Father, Son, and Holy Spirit-even non-Trinitarians like Dale Tuggy have an account of that. The problematic tenets of the Doctrine are specific claims, and to defend the logical consistency of the Doctrine is to defend the logical consistency of those claims. It is easy to lose sight of this. For example, Shieva Kleinschmidt's "Simple Trinitarianism" complements the present paper in important ways, but her focus is on giving $a$ (consistent) interpretation of the Doctrine, rather than arguing that the (correct) interpretation of the Doctrine is consistent. ${ }^{6}$ In other words, her paper is unconcerned with whether her paraphrase (or interpretation) of the Doctrine is reconciling or revising. Thus, her paper, while containing many valuable insights and arguments, contains

${ }^{5}$ This judgment is influenced by the fact that most subsequent philosophers have thought that Berkeley's metaphysics was clearly false. If Berkeley's picture of the world were correct, it would be more plausible (although perhaps still implausible) that his paraphrases were reconciling. See Keller, "Paraphrase, Semantics, and Ontology" §4.2 and (to a lesser extent) $\S 5$ of this essay for related discussion.

${ }^{6}$ Providing a consistent interpretation (or model) of a set of sentences $S$ is a common method of demonstrating the consistency of $S$ in mathematics or logic. This method works, however, only if we already know the logical forms of the statements in S. But that is just what we're trying to determine with respect to (1)-(3). As Branson notes, "Once we define the problem carefully, we can see that what is really being disputed is the very logical form of the [D]octrine itself, and that different proposed solutions correspond to different logical forms attributed to the [D]octrine" (Logical Problem of the Trinity, 2). 
a significant lacuna for anyone wishing to defend the actual historical Doctrine of the Trinity. ${ }^{7}$

In any case, our view is that every solution to the Problem will employ, at least implicitly, some form of paraphrase: orthodox solutions will employ reconciling paraphrases (they're trying to show that the Doctrine is consistent), and heterodox solutions will employ revising paraphrases (they're trying to replace the Doctrine with something consistent). Our focus in this essay is on the role of reconciling paraphrases in defenses of the actual, traditional, Doctrine of the Trinity. ${ }^{8}$ Different people and denominations will have different levels of allegiance to "tradition," but by most Christians' lights it would be preferable if we didn't have to revise a thesis of such central theological importance.

\subsection{The History of the Doctrine}

To understand the importance of preserving the traditional Doctrine, a few words about its history are in order. The most authoritative statement of the Doctrine can be found in the Decrees of the Ecumenical Councils, the first two of which respond to Trinitarian controversies. The Councils continue to have authority in the Roman Catholic, Eastern Orthodox, and many Protestant traditions. The First Council of Nicaea (325 AD) condemns the Arian heresy which says that the Son is created and so not God, and the First Council of Constantinople (381 AD) condemns, among others, the Semi-Arian heresy which says the Holy Spirit is created and so not God.

According to the Exposition of the 150 Fathers from the First Council of Constantinople:

We believe in one God the Father all-powerful ... And in one Lord Jesus Christ, the only-begotten Son of God, begotten from the Father before all the ages ... true God from true God ... consubstantial with the Father ... and in

${ }^{7}$ We defend two other claims that are in apparent tension with Kleinschmidt's paper. First, Kleinschmidt seems to think that her "interpretational" approach to the Problem is novel. To the contrary, we argue in $\S 4$ that every account of the Trinity involves, at least implicitly, a paraphrase-in effect, an interpretation of the Doctrine. Second, her focus is on giving an interpretation of "ordinary sentences about the Father, Son, and Holy Spirit" (Kleinschmidt, "Simple Trinitarianism," 258). But theological discourse is not ordinary language-people use language carelessly in the ordinary business of life, and so we can and should often interpret ordinary speakers as not saying (or writing) exactly what they mean. But as we argue in §5.1, this is much less plausible for theological-especially, conciliardiscourse about the Trinity, which was formulated with great care and after extensive debate and deliberation. (Although this is perhaps offset by the fact that, according to Branson, Logical Problem of the Trinity, 103-108, the creeds included in many conciliar documents were intended to be easily memorized summaries of important doctrine that were understandable to laypeople.)

${ }^{8}$ This is partly because there isn't much of philosophical interest to say about revising paraphrases: there are various practical constraints on what sort of revisions one could reasonably expect people to accept, and there are theological constraints about what revisions could do the theological "work" required of the Doctrine, but both sets of constraints will vary greatly between religious communities. 
the Spirit, the holy, the lordly and life-giving one, proceeding forth from the Father, co-worshipped and co-glorified with Father and Son. ${ }^{9}$

And according to the Letter of Bishops gathered in Constantinople the following year, the Nicene Creed teaches that:

The Father, the Son, and the holy Spirit have a single Godhead and power and substance, a dignity deserving the same honor and a co-eternal sovereignty, in three most perfect hypostases, or three perfect persons. So there is no place for Sabellius's diseased theory. . . . Nor may the blasphemy of Eunomians and Arians and Pneumatomachi prevail. ${ }^{10}$

Finally, Canon 1 of the First Council of Constantinople says,

Every heresy is to be anathematized and in particular that of the Eunomians or Anomoeans, that of the Arians or Eudoxians, that of the Semi-Arians or Pneumatomachi, that of the Sabellians. ${ }^{11}$

The Eunomian (or Anomoian) heresy says the Son's nature is unlike the Father's nature ("Anomoios" means unlike). The Arian (or Eudoxian) heresy says the Son's nature is not the same as the Father's and so the Son is not truly God. The Semi-Arian (or Pneumatomachian) heresy says the Holy Spirit's nature is not the same as the Father's and so the Holy Spirit is not truly God ("Pneumatomachi" means fighter against the Spirit). Finally, the Sabellian heresy says there are no real distinctions among the Father, Son, and Holy Spirit, and hence that the Father is the same person as the Son and Holy Spirit.

The Decrees of the Councils seem to straightforwardly imply (1)-(3). That there is only one God is implied by the Exposition's claim that "We believe in one God" and the Letter's claim that the divine persons "have a single Godhead and power and substance."12 That there are three divine persons is implied by the Letter's claim that "the Father, the Son, and the holy Spirit have a single Godhead . . . in three most perfect hypostases, or three perfect persons." And the Exposition implies each divine person is God. It implies the Father is God, since it says, "We believe in one God the Father." It implies the Son is God, since the Son is "true God from true God," and the Son is "consubstantial with" (i.e., has the same nature as) the Father, who is God. And the Exposition implies the Spirit is God, since it says the Spirit is "co-worshipped and co-glorified with Father and Son." Lewis Ayres, an historian of the early church, notes that the Exposition seems to reflect work on the Holy Spirit by Gregory of Nyssa, who "argues that if we worship the Spirit we must also imagine the Spirit involved in the same activities as Father and Son and hence sharing the

\footnotetext{
${ }^{9}$ Tanner, Decrees, 24.

${ }^{10}$ Tanner, Decrees, 28.

${ }^{11}$ Tanner, Decrees, 31.

${ }^{12}$ See also Isaiah 45.5. Monotheism is, in any case, a core Christian commitment.
} 
same nature."13 Of course, even if the Spirit weren't God, the "Problem of the Bi-nity" would be no easier to solve than the Problem of the Trinity.

\subsection{Content Preservation}

The Doctrine, then, has a long and distinguished history: if we are wrong about the Trinity, orthodox Christian theology is on shaky foundations indeed. Furthermore, the Doctrine was very carefully formulated: it's implausible that some revisionary account of the Trinity is going to be what the Church Fathers were trying to express all along-a revision to what they said but not to what they meant to say (see $\S 5.2$ for more on this possibility). So, it is important, we think, to preserve the traditional Doctrine: for our paraphrases to be reconciling rather than revising. The goal of reconciling paraphrases, recall, is to reconcile apparently inconsistent claims: to clarify the content of the original sentence so as to show that it is consistent with one's other commitments. In our case, reconcilers want to argue that the Doctrine is not self-contradictory: to argue that (1)-(3) are logically consistent. ${ }^{14}$ The basic strategy for such arguments is to find statements $\left(1^{*}\right)-\left(3^{*}\right)$ such that it is reasonable to believe:

$\left(1^{*}\right)$ is logically equivalent to $(1)$

$\left(2^{*}\right)$ is logically equivalent to (2)

$\left(3^{*}\right)$ is logically equivalent to (3)

and,

$\left(1^{*}\right)-\left(3^{*}\right)$ are logically consistent.

Call the first three steps of this strategy Stage 1 and the fourth step Stage 2. There are three important things to note about this strategy.

First, there is a trade-off in how easy it is to complete these two stages. Stage 1 can be made maximally easy by making $\left(1^{*}\right)-\left(3^{*}\right)=(1)-(3)$. But then we will have made no progress on Stage 2, which reduces to our original problem of arguing that (1)-(3) are consistent. Alternatively, Stage 2 can be made maximally easy by, say, letting $\left(1^{*}\right)={ }^{\prime} 1+1=2^{\prime},\left(2^{*}\right)={ }^{\prime} 2+2=4^{\prime}$, and $\left(3^{*}\right)={ }^{\prime} 3+3=6^{\prime}$. But then Stage 1 is maximally difficult. In actual cases, Stage 1 is typically the more difficult.

\footnotetext{
${ }^{13}$ Ayres, Nicaea, 257. See also Gregory of Nazianzus, Oration, 31.28: "I stand . . . able to worship the Father as God, the Son as God, the Holy Spirit as God -'three personalities, one Godhead undivided in glory, honor, substance, and sovereignty'"; Augustine, The Trinity, V.9: "the Father is God and the Son is God and the Holy Spirit is God, and no one denies that this is said substance-wise; and yet we say that this supreme triad is not three Gods but one God."

${ }^{14}$ Two sentences are logically consistent if and only if no contradiction follows from them when they have been properly regimented. Similarly, two sentences are logically equivalent if and only if each follows from the other when properly regimented. Note that logical equivalence isn't a matter of having the same logical form: "Izzy is tall" and "Isaac is tall" have the same logical form, but neither follows from the other.
} 
Second, even though Stage 1 is difficult, it is not as difficult as it would be if it required synonymy-semantic equivalence. Intuitively, synonymy entails logical equivalence, but not vice versa, since semantic equivalence is more "fine-grained" than logical equivalence: some sentences express distinct but logically equivalent propositions. For example, it's plausible that "Pat is Chris's parent" is logically but not semantically equivalent to "Chris is Pat's child": the sentences express distinct propositions, but the propositions they express logically entail each other. Likewise, with " $1<2$ " and " $2>1$." Stage 1 of a reconciliation project does not, then, require the paraphrases and the paraphrased to be synonymous: showing that the literal content of the Doctrine is consistent does not require using paraphrases that express the literal content of the Doctrine. Logically equivalent paraphrases are enough to show that the Doctrine is consistent. However, and this is important, arguing for semantic equivalence-arguing that the paraphrase and the paraphrased "mean the same thing" - is a common and important way of arguing for logical equivalence. It makes sense to ask whether $\left(1^{*}\right)-\left(3^{*}\right)$ mean the same thing as (1)-(3), since an affirmative answer is sufficient for Stage 1's being a success. It's just not necessary.

Third, logical equivalence is not even necessary for Stage 1 to succeed. If $\left(1^{*}\right)-\left(3^{*}\right)$ have the same "logical form" as $(1)-(3)$, or if $\left(1^{*}\right)-\left(3^{*}\right)$ logically entail (1)-(3), that suffices for reconciliation (in conjunction with Stage 2). Indeed, if our ultimate goal is to determine whether some set of claims is metaphysically compossible-whether there is a metaphysically possible world where they are all true-it suffices to show that the paraphrases are necessarily stronger than or equivalent to the originals, and that the paraphrases are metaphysically compossible. In the present context, that would mean showing:

$$
\begin{aligned}
& \square\left(1^{*} \supset 1\right) \\
& \square\left(2^{*} \supset 2\right) \\
& \square\left(3^{*} \supset 3\right) \\
& \text { and, } \\
& \diamond\left(1^{*} \wedge 2^{*} \wedge 3^{*}\right) .
\end{aligned}
$$

Since logically inconsistent statements are metaphysically incompossible, it follows that if a set of statements is metaphysically compossible it is logically consistent. Hence, the Logical Problem of the Trinity can be solved by the above method. That being said, appealing to metaphysical as opposed to logical equivalence and consistency gives rise to difficulties when paraphrasing non-contingent claims. Anyone who has reason to think that (1) -(3) are necessarily true will thereby have reason to think that $\square(1+1=2$ $\supset(1)), \square(2+2=4 \supset(2))$, and $\square(3+3=6 \supset(3))$. And of course, we all have reason to think that $\diamond(1+1=2 \wedge 2+2=4 \wedge 3+3=6)$. But then it looks like providing a reconciling paraphrase of (1)-(3) is trivial for anyone who has reason to think that those statements are necessarily true. To avoid this 
sort of concern, we will focus on logical equivalence and consistency in what follows.

\section{Paraphrase in Existing Accounts}

In the contemporary literature, three approaches to the Trinity dominate: Relative-Identity, Social, and Latin Trinitarian accounts. ${ }^{15}$ We will take the accounts of Peter van Inwagen, Richard Swinburne, and Brian Leftow as representative of these approaches. Social accounts start with three divine persons and try to explain how there could be one God. Latin accounts start with one God and try to explain how there could be three divine persons. Relative-Identity accounts don't try to explain any of this: rather, they defend the consistency of the Doctrine by developing an account that implies that not every relative-identity relation is reducible to classical identity. In what follows, we briefly explicate these accounts and the role of paraphrase therein.

\subsection{Van Inwagen's Relative-Identity Trinitarian Account}

According to Relative-Identity accounts, the Doctrine can be taken at face value: Father, Son, and Spirit are the same God but different divine persons. To explain how the logic of relative identity makes this possible, we need some terminology.

3.1.1 Relative-Identity Terminology. Where " $R$ " stands for a count noun, and where any claim of the form " $a$ is the same $R$ as $b$ " implies a claim of the form " $a$ and $b$ are Rs," call any predicate of the form "is the same $R$ as" a relative-identity predicate (RI-predicate): e.g., "is the same cat as." And call any predicate that is not an RI-predicate an ordinary predicate: e.g., "purrs." The relation any RI-predicate expresses must be both symmetric and transitive but needn't be reflexive (since, e.g., Izzy is not the same cat as herself, as she is not a cat). ${ }^{16}$

Next, say that an RI-predicate $R$ dominates a predicate $F$ just if $R$ forces indiscernibility with respect to F. For example, "being the same cat as" dominates "purrs": if $a$ is the same cat as $b, a$ purrs if and only if $b$ purrs. Call any RI-predicate that dominates every predicate dominant. Finally, call any non-dominant RI-predicate that reduces to a conjunction of dominant RI-predicates and ordinary predicates redundant. The key claim of relative-identity theory - the RI-thesis - is that not every non-redundant RI-predicate is dominant.

3.1.2 Relative Identity and the Doctrine. Van Inwagen uses the RI-thesis to defend the Doctrine as follows. He starts with two undefined RI-predicates ("is the same being as" and "is the same person as") and one undefined ordinary predicate ("is divine"). These predicates can be characterized (but

${ }^{15}$ See McCall and Rea, Philosophical and Theological Essays on the Trinity; Rea, "Trinity"; Rea, Oxford Readings; Howard-Snyder, "Trinity"; and Tuggy, "Trinity."

${ }^{16} \mathrm{~A}$ relation $R$ is symmetric just if, for any $x$ and $y$, if $x$ bears $R$ to $y$, then $y$ bears $R$ to $x$. A relation $R$ is transitive just if, for any $x, y$, and $z$, if $x$ bears $R$ to $y$ and if $y$ bears $R$ to $z$, then $x$ bears $R$ to $z$. A relation $R$ is reflexive just if, for any $x, x$ bears $R$ to $x$. 
not defined) as follows: a being is anything that has causal powers, and a person is any being one can refer to using singular personal pronouns $-\mathrm{a}$ someone. Finally, to be divine is to be necessarily omnipotent, omniscient, perfectly loving, etc. In light of this, van Inwagen claims that anything divine is a being and person, which implies that something is a divine person if and only if it is a divine being.

So, (1)-(3) are initially paraphrased as:

$\left(1_{\mathrm{RI}}\right)$ There is exactly one divine being.

$\left(2_{\mathrm{RI}}\right)$ There are exactly three divine persons.

$\left(3_{\mathrm{RI}}\right)$ Each divine person is a divine being.

Astute readers may notice that these paraphrases simply reiterate (1)-(3) while analyzing "God" as "divine being." The real work done by Relative-Identity is in specifying how we should interpret these claimshow we should understand and so formalize their logical properties. According to van Inwagen's version of the Relative-Identity account, (1)-(3) should be formalized as:

$\left(1_{\mathrm{R}^{*}}\right) \exists x\left(x\right.$ is divine $\wedge \forall y\left(y\right.$ is divine $\left.\left.\supset y={ }_{\text {being }} x\right)\right)$

$\left(2_{\mathrm{R}^{*}}\right) \exists x \exists y \exists z\left(x\right.$ is divine $\wedge y$ is divine $\wedge z$ is divine $\wedge x \neq_{\text {person }} y \wedge x \neq_{\text {person }} z$ $\wedge y \neq_{\text {person }} z \wedge \forall w\left(w\right.$ is divine $\left.\left.\supset\left(w=_{\text {person }} x \vee w=_{\text {person }} y \vee w=_{\text {person }} z\right)\right)\right)$

$\left(3_{\mathrm{RI}^{*}}\right) \forall x\left(\left(x\right.\right.$ is divine $\left.\wedge x=_{\text {person }} x\right) \supset\left(x\right.$ is divine $\left.\left.\wedge x=_{\text {being }} x\right)\right)$

Given the logic of relative identity, these claims are formally consistent. Of course, it is (to say the least) controversial that identity is relative, and hence that this "solution" to the Problem is any solution at all. Our purpose here, though, is just to show how this account makes use of paraphrase. Some might doubt that regimentations like $\left(1_{\mathrm{RI}^{*}}\right)-\left(3_{\mathrm{R}^{*}}\right)$ should be counted as paraphrases. But a regimentation is a logically more perspicuous reformulation of a claim, and that's the definition of "paraphrase." And not just our definition: Quine himself describes the goal of regimentation as being to "paraphrase a sentence of ordinary language into logical symbols." 17 Since Quine is a paradigmatic advocate of the paraphrase technique, ${ }^{18}$ we take it that there can be no argument that classifying regimentations as paraphrases is intolerably idiosyncratic.

That being said, controversy about relative identity leads to the following meta-worry about van Inwagen's account: given that many intelligent and competent speakers deny that (1)-(3) can be properly regimented as $\left(1_{\mathrm{RI}^{*}}\right)-\left(3_{\mathrm{R}^{*}}\right)$, can it plausibly be maintained that the latter are correct (non-revising) paraphrases of the former? We will return to

\footnotetext{
${ }^{17}$ Quine, Word, 159.

${ }^{18}$ Although Quine's rejection of synonymy leads him to say some things about paraphrase that are rejected by later adherents of "Quinean meta-ontology" such as David Lewis and Peter van Inwagen.
} 
this question below. But before moving on, we would like to discuss an important development of van Inwagen's account.

3.1.3 Brower and Rea. Brower and Rea contend that van Inwagen's solution to the Problem is incomplete unless supplemented with a story about the metaphysics of relative-identity relations. ${ }^{19}$ According to the story they tell, there are hylomorphic compounds of form and matter. For example, Socrates is a hylomorphic compound of a rational soul and body. And when Socrates sits, there is an object that comes to be: sitting-Socrates, which is a hylomorphic compound of the sitting-accident as form and Socrates as matter. Finally, though Socrates is not (classically) identical to sitting-Socrates since they are discernible, Socrates is numerically the same as sitting-Socrates since they share the same matter. They are one in number but not in being: Socrates and sitting-Socrates are the same human being but different hylomorphic compounds, as we count human beings by identity of matter but we count hylomorphic compounds by identity. Brower and Rea apply this to the Doctrine as follows. While the divine persons are not hylomorphic compounds (they have no matter, since they are not material), they are like hylomorphic compounds. Each has a personal property that plays the role of form, and each has the divine nature that plays the role of matter. So, the Father is a compound of paternity and the divine nature, the Son is a compound of filiation and the divine nature, and the Spirit is a compound of passive spiration and the divine nature. To be $a \mathrm{God}$ is to be a compound of a personal property and $a$ divine nature (a "divine compound"), and to be the same God is to have the same divine nature (numerically distinct divine compounds are the same God if they have the same divine nature). According to Brower and Rea,

$x$ is a God iff $x$ is a hylomorphic compound whose "matter" is some divine essence; $x$ is the same God as $y$ iff $x$ and $y$ are each hylomorphic compounds whose "matter" is some divine essence and $x^{\prime} \mathrm{s}$ "matter" is the same "matter" as $y^{\prime}$ s. $^{20}$

So, the Father and the Son are the same God but different divine persons, for we count Gods by identity of divine nature but we count divine persons by identity. (1)-(3), then, would be paraphrased by Brower and Rea as follows:

$\left(1_{\mathrm{BR}}\right) \exists x(x$ is a God $\wedge \forall y(y$ is a God $\supset y$ is numerically the same as $x))$

$\left(2_{\mathrm{BR}}\right) \exists x \exists y \exists z$ ( $x$ is a divine person $\wedge y$ is a divine person $\wedge z$ is a divine person $\wedge x \neq y \wedge x \neq z \wedge y \neq z \wedge \forall w$ ( $w$ is a divine person $\supset(w=x \vee$ $w=y \vee w=z))$ )

$\left(3_{\mathrm{BR}}\right) \forall x(x$ is a divine person $\supset x$ is a God $)$

If numerical sameness is not identity, these claims are formally consistent.

\footnotetext{
${ }^{19}$ Brower and Rea, "Material Constitution."

${ }^{20}$ Brower and Rea, "Material Constitution," 142.
} 


\subsection{Swinburne's Social Trinitarian Account}

According to Swinburne's version of Social Trinitarianism, there are three divine beings - beings that are essentially omnipotent, omniscient, perfectly free, etc. And they differ in (active) causal relations: the Father essentially causes the Son to exist, and the Father and Son essentially co-cause the Spirit to exist. The Son, however, doesn't cause the Father, and the Spirit causes neither the Father nor the Son. Nevertheless, they all depend on each other to exist and act-they can't exist or act without each other. They are thus dependent: each depends on something outside itself. They do, however, compose an independent divine society - a society that depends on nothing outside itself. Since its members are eternal and necessary, so is the society. And since its members are omnipotent, omniscient, and perfectly free, so (derivatively) is the society. The society is thus, in some important sense, divine.

For Swinburne, if we want to understand the Doctrine, we should ask how the Council members who formulated the Doctrine understood it. He writes,

If 'there is only one God' meant 'there is only one divine individual', then the doctrine of the Trinity would be manifestly self-contradictory. So clearly Church councils ... must have understood 'there is only one God' in a somewhat subtler sense-since no person and no Council affirming something which they intend to be taken with utter seriousness can be read as affirming an evident contradiction. What in denying tritheism, the view that there are three Gods, were Councils ruling out? I suggest that they were denying that there were three independent divine beings, any of which could exist without the other; or which could act independently of each other.... But then how is the claim that each of the individuals is 'God' to be understood? Simply as the claim that each is divine-omnipotent, perfectly good, etc. ${ }^{21}$

Swinburne thus straightforwardly uses paraphrase to solve the Problem: he takes "God" to be ambiguous between "divine being" and "independent divine being," and for (1) to use "God" in the latter sense while (3) uses "God" in the former sense. Once this is made explicit, there is no suggestion of contradiction:

$\left(1_{\mathrm{ST}}\right)$ There is exactly one independent divine being (i.e., the divine society).

$\left(2_{\mathrm{ST}}\right)$ There are exactly three divine persons.

$\left(3_{\mathrm{ST}}\right)$ Each divine person is a divine being.

There are many objections to Swinburne's proposal: perhaps most importantly, it implies that in an important sense of "God" - the sense in which "the Father is God" is true-there is more than one God. Our

\footnotetext{
${ }^{21}$ Swinburne, Christian God, 180-181.
} 
purpose, however, is just to argue that it makes use of paraphrase. And this it clearly does. ${ }^{22}$

\subsection{Leftow's Latin Trinitarian Account}

Leftow's "Latin Trinitarian" account is best explained by analogy. Imagine that Jane, a Rockette dancer, travels back in time twice so that she can simultaneously perform three roles: that of leftmost, middle, and rightmost Rockette. The resulting performance would then involve only one being dancing on stage: Jane. But there would be a legitimate sense in which there are three dancers on stage: the leftmost, middle, and rightmost Rockette. There are, then, two ways to count dancers: by beings that perform dance-roles and by dance-roles performed by beings. More generally, there are two ways to count Fs: by occupants of F-roles and by F-roles occupied. On the first way, since there's only one being that dances, there's only one dancer. On the second way, since there are three occupied danceroles, there are three dancers. So, on the second way, though there's only one being that dances, and though each dancer is a being that dances, there are three dancers. As Leftow puts it:

There are at least two ways to count dancers. One simply counts the substances onstage. The other also counts substances, but counts them in terms of the roles they play, so that one substance counts as two dancers if playing two roles. Ordinarily, the dancers would not all be one woman, and so there would be many no matter which way we counted. So ordinarily, we needn't bear in mind that there is more than one way to count dancers. But a time travel case isn't ordinary, and given time travel, we must bear this in mind, for if we count by roles there are many dancers, but if we count by substances playing the roles there is just one. Given time travel, the two ways to count yield different results, and so if time travel became common, description of some situations might become more complicated, and we might want more information than we now do if we are to be confident we're speaking accurately. But both ways of counting are perfectly ordinary; neither "runs counter to our normal ways of using language." 23

The analogy with the Trinity is clear: God is like Jane. There is only one divine living being, God, but that being lives His life in three streams, each of which counts as the life of a person. God is, as it were, playing three roles at once: that of Father, Son, and Spirit. On this account, there's clearly only one divine being: God. But how many divine persons are there? We can count divine persons by counting divine beings that live a personal

\footnotetext{
${ }^{22}$ One might think that Swinburne must be offering a revising rather than a reconciling paraphrase here, since one might think $\left(1_{\mathrm{ST}}\right)$ isn't logically equivalent to $(1)$, since $\left(1_{\mathrm{ST}}\right)$, but not (1), implies that there is an independent being. But Swinburne's paraphrase is intended to be reconciling: he is arguing that (1) is misleading as to the logical properties of the claim that the Church Fathers were trying to assert, and that $\left(1_{\mathrm{ST}}\right)$ is a more perspicuous expression of that claim. That is, he is arguing that $\left(1_{\mathrm{ST}}\right)$ expresses the very same claim as - and hence a claim logically equivalent to-the claim that the Church Fathers were using (1) to express. Thanks to an anonymous referee for pressing us to be clearer on this point.
}

${ }^{23}$ Leftow, “On Hasker," 334. 
life or by counting personal lives lived by a divine being. On the first way, since there's only one divine being, there's only one divine person. On the second way, since there are three personal lives, there are three divine persons. So, on the second way, though there's only one divine being, and though each divine person is a divine being, there are three divine persons.

How does Leftow's account make use of paraphrase? On this view, the crucial step for rendering (1)-(3) consistent is distinguishing between the one divine being and the "personal lives" of Father, Son, and Spirit. (1)-(3) are then paraphrased as follows:

$\left(1_{\text {LT }}\right)$ There is exactly one divine being.

$\left(2_{\text {LT }}\right)$ There are exactly three divine "personal lives."

$\left(3_{\mathrm{LT}}\right)$ Each divine "personal life" is lived by a divine being.

$\left(1_{\mathrm{LT}}\right)-\left(3_{\mathrm{LT}}\right)$ are clearly logically consistent. As with the other proposals, there are objections to Leftow's: perhaps most importantly, it implies that in some sense there's only one divine person. But again, our purpose here is just to argue that it makes use of paraphrase. ${ }^{24}$

\section{The Master Argument}

We have seen that all three of the main accounts of the Trinity rely on paraphrase. And indeed, we think that every coherent and orthodox account of the Trinity is committed, at least implicitly, to the success of some paraphrase. Consider again the Doctrine:

(1) There is exactly one God.

(2) There are exactly three divine persons.

(3) Each divine person is God.

The Problem is essentially that these claims seem inconsistent. There are only three possible responses to the Problem: Embrace Inconsistency, Eschew Orthodoxy, and Paraphrase.

Embrace Inconsistency: One might say that (1)-(3) really are inconsistent and accept them anyway. Perhaps this view can be attributed to certain Christian mystics, although we doubt it. If so, they are confused: this response is incoherent, and so not a solution to the Problem at all. ${ }^{25}$ What might seem like a more plausible version of this strategy would be to say that while (1)-(3) are literally contradictory, they non-literally communicate

\footnotetext{
${ }^{24}$ Leftow, "Modes without Modalism," offers a related but different account, on which God generates three personal life streams, which in turn constitute three persons. This account involves different paraphrases and the objections we raise for Leftow's account here do not obviously apply to this alternative account.

${ }^{25}$ At least if Dialetheism (the view that there are true contradictions) is false. But even Dialetheists think that only certain special contradictions are true, and it's not obvious that the Doctrine is special in this way.
} 
or signify important theological truths. This, however, is really to Eschew Orthodoxy. ${ }^{26}$

Eschew Orthodoxy: One might say that (1)-(3) really are inconsistent and reject one or more of them. But this would involve rejecting Christian orthodoxy, as discussed in §2.2. To deny (1) is to deny monotheism ("we believe in one God"). To deny (3) is to deny that the Father is God, the Son is God, or the Holy Spirit is God. But to deny that the Son is God is to commit the Arian heresy, to deny that the Holy Spirit is God is to commit the semi-Arian heresy, and to deny that the Father is God is to reject a central tenet of all Abrahamic religions. Finally, to deny (2) contradicts the First Council of Constantinople's claim that the Father, Son, and Spirit are "three perfect persons," a central teaching of almost all Christian denominations.

Paraphrase: Finally, one might say that while the Doctrine seems inconsistent, it is not really inconsistent. Merely asserting this might be rational for some people, ${ }^{27}$ but it is not an attempt to actually solve the Problem: it is not an account of the Trinity. Even a proof that the Doctrine were true would only show that there is a solution to the Problem,; it wouldn't itself be a solution. A solution must allow us to see, at least through a glass darkly, how (1)-(3) are consistent, and paraphrase provides one way to do that. But we think that every way of doing that will rely, at least implicitly, on the success of some paraphrase. For example, some people hold that conceivability entails, or is evidence for, possibility. According to such people, conceiving of a situation where (1)-(3) are true would provide evidence that they're consistent which might not seem to make use of paraphrase. We hold, however, that the only way to conceive of (1)-(3) being true is to conceive of a situation where some semantically, logically, or metaphysically equivalent set of sentences-i.e., paraphrases-such as $\left(1_{\mathrm{LT}}\right)-\left(3_{\mathrm{LT}}\right)$, are true, so the purported contrast between conceivability and paraphrase is spurious. ${ }^{29}$ Likewise, we sometimes demonstrate the consistency of some set of sentences $S$ by providing a "model" of the sentences in $S$. But providing a model of $S$ is, in effect, to provide a reinterpretation

\footnotetext{
${ }^{26}$ Assuming that the Doctrine consists of sentences. If it consists of propositions non-literally "expressed" by (1)-(3), this approach might not be revisionary. However, it then becomes less clear that we know what the Doctrine is - that we have actually latched onto the relevant non-literal "contents" of (1)-(3). In any case, the considerations mentioned in connection with Eschewing Orthodoxy would seem to indicate that defenders of the Doctrine had better take (1)-(3) to be literally true.

${ }^{27}$ This is roughly what Tuggy calls "Positive Mysterianism" ("On Positive Mysterianism").

${ }^{28}$ Swinburne, Christian God, ch. 8, gives a "proof" of the Doctrine, but his argument relies on controversial and uncertain principles, as Swinburne himself acknowledges.

${ }^{29}$ If we could "directly" conceive of a situation where (1)-(3) were true, they wouldn't seem inconsistent! (On the other hand, if "direct conception" is allowed to be theory-laden, such that it makes sense to think that we may eventually be able to "directly conceive" the joint possibility of (1)-(3) via the lens of theory $T$, this is in no tension with the fact that (1)-(3) now seem inconsistent. But in this case, we hold that "direct conception via the lens of theory $T^{\prime \prime}$ will involve a commitment to the success of some paraphrase proposal-a proposal that states (1)-(3) in the language of $T$.)
} 
of $S$ with the same "logical form," so a model-theoretic consistency argument will still employ, in effect, Stages 1 and 2 of the paraphrase strategy outlined above. (And as noted there, to provide a model of a statement one must already know its logical form, but disputes about the Trinity are disputes about the Doctrine's logical form.) Finally, as argued at the end of §3.1.2, regimentations are a form of paraphrase, so any solution to the Problem that involves regimentation or logical revision-relative identity solutions, most obviously, but also other logically heterodox views ${ }^{30}-$ will invariably involve or be committed to paraphrases (regimentations) of (1)-(3).

So, we are inclined to think that any solution to the Problem is at least implicitly committed to there being reformulations of (1)-(3) that indicate that they are merely apparently inconsistent-e.g., that provide evidence that (1)-(3) are consistent after all. But these would just be reconciling paraphrases. Hence, we think that any coherent and orthodox account of the Trinity must appeal, at least implicitly, to that technique.

Here is another way of putting the point. Naively, (1)-(3) would be regimented as:

$\left(1_{\mathrm{N}}\right) \exists x(x$ is a God $\wedge \forall y(y$ is a God $\supset y=x))$

$\left(2_{\mathrm{N}}\right) \quad \exists x \exists y \exists z$ ( $x$ is a divine person $\wedge y$ is a divine person $\wedge z$ is a divine person $\wedge x \neq y \wedge x \neq z \wedge y \neq z \wedge \forall w$ ( $w$ is a divine person $\supset(w=x \vee$ $w=y \vee w=z)))$

$\left(3_{\mathrm{N}}\right) \quad \forall x(x$ is a divine person $\supset x$ is a God $)$

But $\left(1_{N}\right)-\left(3_{N}\right)$ really are inconsistent, so long as the predicates are interpreted uniformly. So, any coherent and orthodox account of the Trinity is at least implicitly committed to a non-standard regimentation of (1)-(3). But, as argued above, a non-standard regimentation is a form of paraphrase. ${ }^{31}$ While it's often acknowledged that any solution to the Problem will (implicitly or explicitly) involve regimenting (1)-(3), we are arguing that this fact has some un- or under-appreciated implications for theorizing about the Trinity.

\section{Complications}

We have seen that for an account of the Doctrine to be orthodox, the paraphrases involved must be reconciling rather than revising. Such

\footnotetext{
${ }^{30}$ Such as the plural logic solution defended in Bohn, "Logic of the Trinity." Bohn's view also involves paraphrase in a more trivial sense: he paraphrases (3) as $\left(3_{\mathrm{PL}}\right) \mathrm{God}=$ the Father, the Son, the Holy Spirit, where "the Father, the Son, the Holy Spirit" is a plural term and ' $=$ ' is interpreted collectively. See Bohn, "Logic of the Trinity," for further discussion.

${ }^{31}$ More carefully: a regimentation is, or is a recipe for constructing, a logically more perspicuous reconciling paraphrase. One could describe the logical form of a statement without actually regimenting it, of course. But one's description of that logical form will correspond to some regimentation, and the accuracy of that description will stand or fall with the acceptability of that regimentation. This is the sense in which every purported solution to the Problem is at least implicitly tied to the success of some paraphrase.
} 
reconciling paraphrases often aim to be semantically, logically, or metaphysically equivalent to the sentences they paraphrase, but we saw that this is not necessary: paraphrases that semantically, logically, or metaphysically entail the sentences they paraphrase will work as well. Since semantic equivalence entails logical and metaphysical equivalence, arguments about the legitimacy of various paraphrase proposals often focus on the question of semantic equivalence. That normally does no harm, but it is wise to keep the actual necessary conditions on successful paraphrase in mind.

Since there are some semantically equivalent (i.e., synonymous) sentences, there are some successful paraphrases. ${ }^{32}$ It is even plausible that there are some philosophically interesting successful paraphrases: ordinary speakers will typically grant that, e.g., "There is a crack in my favorite vase" and "My favorite vase is cracked" are two ways of saying the same thing. ${ }^{33}$ In many cases, however, paraphrase proposals are less intuitive: ordinary speakers will almost universally deny that, e.g., "There's a chair in Izzy's closet" and "There are some simples arranged chair-wise in Izzy's closet" are two ways of saying the same thing. ${ }^{34}$ In such "hard cases," the paraphraser must tell a meta-semantic story (a story about how expressions get their meanings) that makes it plausible that, e.g., "There's a chair in Izzy's closet" comes to express the same proposition as, or a proposition true in the same worlds as, "There are some simples arranged chair-wise in Izzy's closet." We think that, given certain not implausible presuppositions, such meta-semantic stories can in principle be told. ${ }^{35}$ But they raise additional complications. In what follows, we investigate the prospects for "easy" and "hard" paraphrases of (1)-(3).

\subsection{Easy Paraphrases?}

The easiest cases of paraphrase involve "loose talk" and other locutions used out of convenience or sloppiness: cases where, broadly speaking, we don't say what we mean. For example, people often say things like "I'm parked in the Gallagher lot" as a sort of convenient abbreviation for "My car is parked in the Gallagher lot." ${ }^{36}$ In the present context, however, we are talking about a carefully formulated theological doctrine: one it would be difficult to argue is a case of loose talk or not saying what one means. There still might be an "easy" paraphrase, however, if ordinary speakers or some relevant class of theologians agree that the paraphrased statements

\footnotetext{
${ }^{32} \mathrm{At}$ least assuming that not every pair of synonymous sentences is equally perspicuous.

${ }^{33}$ See Keller, "Paraphrase and the Symmetry."

${ }^{34}$ See van Inwagen, Material Beings.

${ }^{35}$ See Keller, "Paraphrase, Semantics, and Ontology."

${ }^{36}$ Is this a revising or reconciling paraphrase? Well, the two sentences plausibly differ in semantic meaning, but "My car is parked in the Gallagher lot" expresses the claim one presumably originally believed and intended to communicate by uttering "I'm parked in the Gallagher lot." So, while this paraphrase might involve a revision in what one (literally) says, it does not involve a revision in what one believes.
} 
and their paraphrases are two ways of saying the same thing. In $\S 6$ we consider whether this is the case with any of the three main accounts of the Trinity.

\subsection{Hard Paraphrases?}

When it's counterintuitive that a statement and its paraphrase mean the same thing, the paraphraser must provide some sort of explanation for why our intuitions are wrong (or at least why the paraphrase is logically or metaphysically equivalent to the paraphrased). One strategy is to tell a meta-semantic story that makes such unintuitive paraphrases credible. ${ }^{37}$ Finding such a story is often difficult, however, and those difficulties are magnified in the present case, since (1)-(3) are not "ordinary language" assertions, but precisely formulated theological doctrines. The meta-semantic theses that make some "hard" paraphrases plausible often hinge on the fact that ordinary language is loose and accommodating: ordinary language locutions aren't intended to be perspicuous representations of the underlying metaphysics of the world, and so they plausibly aren't required to be perspicuous in order to be true, as long as they represent the world as it is. ${ }^{38}$ Carefully formulated metaphysical doctrines, on the other hand, are generally intended to be perspicuous in this sense. While theology isn't analytic metaphysics, it is more like analytic metaphysics than ordinary language, and this creates an obstacle for making initially implausible paraphrases more plausible upon further reflection, including further reflection on the meta-semantics of theological language.

\section{Implications}

How does all of this bear on the paraphrase proposals we looked at in $\S 3$ ? We do not have the space to answer this question properly - that task would require a paper, or three, unto itself. Our goal here is merely to sketch the beginnings of an answer in order to show that the full answer is likely to be interesting and important. We will focus on two questions:

(1) Would ordinary speakers (or some relevant class of theologians) grant that the paraphrases are simply two different ways of saying the same thing? Are the paraphrases "easy" (intuitively content-preserving)?

(2) For paraphrases that are "hard" (not intuitively content-preserving), is there a plausible meta-semantic story to be told about why the

\footnotetext{
${ }^{37} \mathrm{~A}$ complication arises from the fact that whether a meta-semantic story is credible depends on (what one takes to be) the correct theory of the world. Recall the discussion of Berkeley in $\S 2$.

${ }^{38}$ "The average mother has 2.4 children" and "The number of children divided by the number of mothers is 2.4 " are metaphysically, but not semantically, equivalent; we take it that the latter is a more perspicuous representation of reality than the former, since, despite functioning grammatically like a referring expression, there is nothing to which "the average mother" refers.
} 
paraphrased statements have the same truth-conditions as the paraphrases (more carefully, about why they are logically or metaphysically weaker than or equivalent to the paraphrases)?

\subsection{Van Inwagen}

Perhaps surprisingly, we think that the relative-identity paraphrases are easy cases. While contemporary philosophers and mathematicians often find relative identity counterintuitive, we submit that ordinary folk and theologians 1,000 years ago (or today) would find nothing surprising in the account of "sameness" given by Relative-Identity theorists. They would certainly find nothing surprising about claiming that, e.g., if I made two sculptures out of the same hunk of Play-Doh (in sequence), sculpture-one might be a different sculpture than sculpture-two, despite the fact that sculpture-one is the same hunk of clay as sculpture-two. Of course, there are puzzles about just how to make accounts like this work smoothly, but those aren't problems about conflict with ordinary usage. The folk generally just do not use "same" to mean identity as understood by classical logicians: relative identity is "deviant" relative to contemporary philosophical orthodoxy, but not ordinary use. Paraphrases like $\left(1_{\mathrm{RI}}\right)-\left(3_{\mathrm{RI}}\right)$ might seem revisionary to those of us who learned classical logic on our mother's knee, but that's not everyone, and critically, it's not the theologians who were struggling to formulate (what are now) the canonical statements of the Doctrine in the first place. After all, those theologians antedated the advent of classical logic by a thousand years. Of course, that doesn't mean that (1)-(3) don't seem surprising to ordinary folk. But that's not because they find relative identity surprising; it's because they find the relative identity relations attributed to the divine persons by $\left(1_{\mathrm{RI}}\right)-\left(3_{\mathrm{RI}}\right)$ surprising.

\subsection{Swinburne}

Swinburne's paraphrases fare less well along this metric. We suspect that ordinary folk and theologians, now or 1,000 years ago, would balk at the claim that, if Christianity is true, there's an important sense in which the Father is not God (the sense of "God" in which monotheism is true). So, Swinburne's paraphrases are not "easy." There also does not seem to be an obvious meta-semantic story about how the word "God" could have come to be associated with the two different meanings Swinburne postulates ("independent divine being" and "divine being"). Traditionally, it was not part of the meaning of "god" that gods were independent in Swinburne's sense: it was a substantive claim that the God of Abraham was independent. Furthermore, if there were two uses of "God" in play it would be peculiar for the Doctrine to have been formulated in such a needlessly confusing manner.

On the other hand, Swinburne claims that,

There is an ambiguity in the Greek and Latin of the creeds, which justifies a different understanding of $\theta \varepsilon \hat{\zeta} \varsigma$ and deus (normally both translated into English as 'God') in different places in the creeds.... Given this ambiguity, 
it is not implausible to read the creeds as asserting that three divine individuals (in my sense) together constitute one God (in my sense). The creeds are less paradoxical in Greek or Latin than their English translation makes them. ${ }^{39}$

If this were relevantly true, it would provide powerful support for Swinburne's paraphrases. But in the Athanasian Creed, for example, the Latin that is translated as "the Father is God, the Son God, the Holy Spirit God; and yet there are not three Gods, but there is one God" 40 uniformly uses "deus" (and its cognates): Ita Deus Pater, Deus Filius, Deus Spiritus Sanctus. Et tamen non tres dii, sed unus est Deus. Of course, this doesn't show that "deus" is unambiguous, but the appearance of contradiction does not disappear in the original Latin, as Swinburne seems to suggest. Furthermore, the Athanasian Creed contains multiple phrases of the form "the Father is $X$, the Son is $X$, the Holy Spirit is $X$; and yet there are not three $X s$, but there is one $X$, , where "eternal" (aeternus), "almighty" (omnipotentes), "Lord" (Dominus), and so on are substituted for "X." Since "aeternus," "omnipotentes," "Dominus," etc. are not ambiguous, it can't generally be true that claims of the form "the Father is $X$, the Son is $X$, the Holy Spirit is $X$; and yet there are not three $X s$, but there is one $X$ " are supposed to be read with " $X$ " having a different meaning in its last appearance, which suggests that "deus" is supposed to be interpreted the same in "sed unus est Deus" as it is in "Ita Deus Pater, Deus Filius, Deus Spiritus Sanctus."

\subsection{Leftow}

Leftow's paraphrases also don't seem to be "easy": it just doesn't seem true that we can "count persons" by counting beings that live personal lives or by counting personal lives lived by beings, and there isn't an obvious meta-semantic story about why that seeming is not veridical. We grant that if time-travel became common we might start counting persons this way. But time travel isn't common, and so our linguistic practices have not evolved to accommodate it. What Leftow needs and indeed claims is that our counting practices wouldn't need to evolve to accommodate time travel: that we already count things, or at least persons, in the way he suggests.

Is this the case? We think not. Imagine some small town containing three restaurants: one serving breakfast, one serving lunch, and one serving dinner. Suppose the town's one and only chef works at all three restaurants. How many chefs are there in town? There is only one answer, and the answer is "one": the number we get by counting beings that are chefs, not "chef roles" occupied by beings. Likewise, if a student is taking all three of her courses from Prof. Smith, there is only one answer to the question "How many professors does the student have this semester?," and the answer is "one": the number we get by counting beings that are professors, not "professor roles" occupied by beings. Even if there are some

\footnotetext{
${ }^{39}$ Swinburne, Christian God, 181-182.

${ }^{40}$ Kelly, Athanasian Creed, 18.
} 
predicates such that the bearers of those predicates can be counted in the two ways Leftow suggests - what we might call "dual predicates" - other predicates, including "person," are not dual. Even if ordinary English allows us to say that there are three dancers on stage, it requires us to say that there is only one person up there.

It is important that we get this result using Leftow's own example, since whether a predicate is dual plausibly depends on context. If we ask how many students a professor has, where we are interested in the professor's workload, it is natural to "double count" students in more than one of the professor's classes: to count student roles occupied by beings, rather than beings that occupy student roles. However, if we were interested in the number of students that a professor knows personally, we would count beings that occupy student roles rather than student roles occupied by beings. Is there any context where we would "count persons" by person roles occupied by beings? The best case we can come up with is an amendment of Leftow's Rockette case: perhaps fire-department code only allows "two people on stage" at any given time. If, upon being written up for a code violation, the club owner protested that there was really only one person on stage during Jane's performance, the club owner's protest would be rightly dismissed. But this isn't because it's literally true that there was more than one person on stage during the performance. Rather, it seems clear that this is because the intent of the law obviously has to do with overcrowding: it has to do with how much space is taken up by the people on stage. If, instead of being a time traveler, Jane performed her routine via some sort of tri-location, the code violation would be just as clear as in the time-traveler case. But we take it that in the case of tri-location there is obviously no sense in which there are literally three people on stage. So, the aptness of the code violation does not require it to be literally true that there were more than two people on stage. Hence, even this "best case" does not support the conclusion that "person" has a dual interpretation.

But perhaps Leftow could argue that "person" in ordinary English does not mean the same thing as "prosoppon" in the mouths of those who formulated the Doctrine. This wouldn't be a meta-semantic story where ordinary uses of "person" are amenable to counting in the dual way Leftow suggests. Rather, it would be a story about what the Church Fathers who were responsible for formulating the Doctrine intended to be saying when they said there were three divine persons. Thus, it may be possible for Leftow to argue that there is a significant gap between how the Church Fathers thought about prosopa and how we think about persons: a gap that warrants thinking that $\left(1_{\mathrm{LT}}\right)-\left(3_{\mathrm{LT}}\right)$ are what the Church Fathers meant to communicate when saying things like (1)-(3). What is crucial for Leftow's account is that "prosoppon," as used by the Church Fathers, is dual-not that "person" is. We simply note here that Leftow hasn't given any argument for this claim; his examples focus, rather, on count nouns in English. And we're skeptical that such an argument is there to be made: if "prosoppon" 
were dual, wouldn't philologists have told us by now? We remain open to correction on this matter, however.

\section{Conclusion}

There is, of course, much more to be said about paraphrase and the Trinity: our aim here has just been to lay the groundwork for future research. We have argued that for anyone wishing to defend the traditional Doctrine, it is important to attend - with an eye to the distinction between revising and reconciling paraphrases - to the plausibility of the paraphrases to which her theory is committed. Furthermore, we have tentatively concluded that explicit consideration of the nature of paraphrase provides support for Relative-Identity as against Social or Latin Trinitarian accounts. We are not, of course, making any claim about the other philosophical or theological hurdles facing these views, or their overall merits and demerits. We are merely pointing out that insofar as we are interested in showing that the Doctrine is consistent, rather than replacing it with something consistent, both Social and Latin Trinitarians face a hurdle that Relative-Identity Theorists do not. Our more general and important conclusion is that explicit thought about paraphrase is important for evaluating accounts of the Trinity. ${ }^{41}$

Kutztown University Saint Joseph's University

\section{References}

Augustine. 1991. The Trinity. Translated by Edmund Hill (New City Press).

Ayres, Lewis. 2004. Nicaea and its Legacy (Oxford University Press).

https://doi.org/10.1093/0198755066.001.0001

Bohn, Einar Duenger. 2011. “The Logic of the Trinity." Sophia 50: 363-374. https://doi.org/10.1007/s11841-011-0265-1

Branson, Beau. 2014. The Logical Problem of the Trinity. Philosophy Ph.D. Dissertation (University of Notre Dame). https://curate.nd.edu/show/j386057684n.

Brower, Jeffrey, and Michael Rea. 2005. "Material Constitution and the Trinity." Faith and Philosophy 22: 487-505. https://doi.org/10.5840/faithphil200522134

Burgess, John, and Gideon Rosen. 2005. “Nominalism Reconsidered." In Oxford Handbook of the Philosophy of Mathematics and Logic, edited by Stewart Shapiro (Oxford University Press), 515-535. https://doi.org/10.1093/0195148770.003.0016 Gregory of Nazianzus. 2002. "Oration 31." In On God and Christ. Translated by Lionel Wickham (St. Vladimir's Seminary Press), 117-147.

\footnotetext{
${ }^{41}$ We thank audiences at the Evangelical Philosophical Society Annual Meeting 2016, the Notre Dame Center for Philosophy of Religion Discussion Group 2017, and the Society of Christian Philosophers Eastern Region Conference 2017. In particular, we thank Beau Branson, Lorraine Juliano Keller, Chris Menzel, Mark Murphy, Michelle Panchuk, Mike Rea, and three anonymous referees for helpful comments on previous drafts.
} 
Howard-Snyder, Daniel. 2015. "Trinity." In the Routledge Encyclopedia of Philosophy (Taylor and Francis). https://doi.org/10.4324/9780415249126-K105-2

Keller, John A. 2015. "Paraphrase, Semantics, and Ontology." In Oxford Studies in Metaphysics 9, edited by Karen Bennett and Dean Zimmerman (Oxford University Press), 89-128. https://doi.org/10.1093/acprof:oso/9780198729242.003.0006

Keller, John A. 2017. "Paraphrase and the Symmetry Objection." Australasian Journal of Philosophy 95: 365-378. https://doi.org/10.1080/00048402.2016.1168457

Kelly, J. N. D. 1964. The Athanasian Creed (A. \& C. Black).

Kleinschmidt, Shieva. 2016. "Simple Trinitarianism and Feature-Placing Sentences." Faith and Philosophy 33: 257-277. https://doi.org/10.5840/faithphil201633365

Leftow, Brian. 2004. "A Latin Trinity." Faith and Philosophy 21: 304-333. https://doi.org/10.5840/faithphil200421328

Leftow, Brian. 2007. "Modes without Modalism." In Persons: Human and Divine, edited by Peter van Inwagen and Dean Zimmerman (Oxford University Press).

Leftow, Brian. 2012. "On Hasker on Leftow on Hasker on Leftow." Faith and Philosophy 29: 334-339. https://doi.org/10.5840/faithphil201229333

McCall, Thomas, and Michael Rea, eds. 2009. Philosophical and Theological Essays on the Trinity (Oxford University Press). https://doi.org/10.1093/acprof:oso/9780199216215.001.0001

Quine, W. V. O. 1960. Word and Object (The MIT Press).

Rea, Michael, ed. 2009a. Oxford Readings in Philosophical Theology: vol.1 Trinity, Incarnation, and Atonement (Oxford University Press).

Rea, Michael. 2009b. "Trinity." In Oxford Handbook of Philosophical Theology, edited by Thomas Flint and Michael Rea (Oxford University Press), 403-429.

Swinburne, Richard. 1994. The Christian God (Oxford University Press). https://doi.org/10.1093/0198235127.001.0001

Tanner, Norman. 1990. Decrees of the Ecumenical Councils, vol.1 (Georgetown University Press).

Tuggy, Dale. 2011. “On Positive Mysterianism." International Journal for Philosophy of Religion 69: 205-226. https://doi.org/10.1007/s11153-010-9237-6

Tuggy, Dale. 2016. "Trinity." In the Stanford Encyclopedia of Philosophy (Winter 2016). Edited by Edward N. Zalta, www.plato.stanford.edu/archives/win2016/ entries/trinity/.

Van Inwagen, Peter. 1988. "And Yet They Are Not Three Gods But One God." In Philosophy and the Christian Faith, edited by Thomas V. Morris (University of Notre Dame Press). Reprinted in van Inwagen 1995.

Van Inwagen, Peter. 1990. Material Beings (Cornell University Press).

Van Inwagen, Peter. 1995. God, Knowledge, and Mystery (Cornell University Press). 